OPEN ACCESS

Edited by:

Daigo Hashimoto,

Hokkaido University, Japan

Reviewed by:

Daniel Peltier,

University of Michigan, United States

Yongxia Wu,

Medical University of South Carolina,

United States

${ }^{*}$ Correspondence:

Motoko Koyama

mkoyama@fredhutch.org

Specialty section:

This article was submitted to Alloimmunity and Transplantation,

a section of the journal

Frontiers in Immunology

Received: 27 May 2021

Accepted: 25 August 2021

Published: 14 September 2021

Citation:

Koyama M and Hill GR (2021)

Mouse Models of Antigen

Presentation in Hematopoietic

Stem Cell Transplantation.

Front. Immunol. 12:715893. doi: 10.3389/fimmu.2021.715893

\section{Mouse Models of Antigen Presentation in Hematopoietic Stem Cell Transplantation}

\author{
Motoko Koyama $^{1 *}$ and Geoffrey R. Hill ${ }^{1,2}$ \\ ${ }^{1}$ Clinical Research Division, Fred Hutchinson Cancer Research Center, Seattle, WA, United States, ${ }^{2}$ Division of Medical \\ Oncology, University of Washington, Seattle, WA, United States
}

Allogeneic stem cell transplantation (alloSCT) is a curative therapy for hematopoietic malignancies. The therapeutic effect relies on donor $T$ cells and NK cells to recognize and eliminate malignant cells, known as the graft-versus-leukemia (GVL) effect. However, off target immune pathology, known as graft-versus-host disease (GVHD) remains a major complication of alloSCT that limits the broad application of this therapy. The presentation of recipient-origin alloantigen to donor T cells is the primary process initiating GVHD and GVL. Therefore, the understanding of spatial and temporal characteristics of alloantigen presentation is pivotal to attempts to separate beneficial GVL effects from detrimental GVHD. In this review, we discuss mouse models and the tools therein, that permit the quantification of alloantigen presentation after alloSCT.

\section{Keywords: transplantation, antigen presentation, allogeneic stem cell transplantation, graft-versus-host disease,} graft-versus-leukemia effects

\section{INTRODUCTION}

Allogeneic stem cell transplantation (alloSCT) remains a curative therapy for a broad range of hematopoietic malignancies including acute myeloid leukemia (AML) and myelodysplastic syndrome. The therapeutic effect largely resides in graft-versus-leukemia (GVL) effects where graft-derived donor T cells and NK cells recognize allogeneic, hematopoietic or tumor-associated antigens. Unfortunately, this process is closely related to adverse immune effects, namely graftversus-host disease (GVHD), where donor T cells attack normal recipient tissue. To date, the separation of beneficial GVL from detrimental GVHD remains the greatest unmet need in alloSCT.

The immunological pathways of both GVL and GVHD are initiated by the presentation of allogeneic antigens to donor T cells: Autologous or syngeneic (from an identical twin donor) transplants do not induce classical GVL or GVHD due to the lack of alloreactivity (1). AlloSCT using rigorous T cell-depletion (TCD) prevents severe GVHD but increases leukemia relapse (2-4), indicating that the recognition of alloantigens by the donor $\mathrm{T}$ cell is essential in disease pathophysiology. Therefore, studies to elucidate potential spatial and temporal differences in antigen presentation within GVL and GVHD have been undertaken (i.e. what types of antigen presenting cells (APC) and donor T cell subsets are involved, in which organs, and at what time after transplant?). 
When choosing mouse models to study GVHD, at least three factors should be considered. Firstly, who are the cellular mediators of disease? As we previously reviewed $(5,6)$, both donor CD4 and CD8 $\mathrm{T}$ cells which recognize alloantigens presented by MHC class II (MHC-II) and class I (MHC-I) respectively, can mediate distinct patterns of GVL and GVHD. Host APC initiate both GVHD and GVL, in contrast, donor APC predominantly invoke GVHD but not GVL (7-9). To define the specific pathways of MHC-I vs MHC-II dependent T cell GVHD and the donor $v s$. host APC involved, alloantigen-specific T cell receptor (TCR) transgenic $\mathrm{T}$ cells are useful tools, particularly when combined with mutant mice bearing defined genetic defects in antigen presentation. Secondly, donor $\mathrm{T}$ cell responses can generally be initiated by one of two types of alloantigen presentation. One is the presentation of host minor histocompatibility antigens (miHAs) derived from polymorphic proteins which are present in recipients but not donors $(10,11)$. A miHA is presented by MHC which is shared by the donor and the host, and donor $\mathrm{T}$ cells recognize miHAs in the same way as pathogen-derived antigens are seen. This process includes a process known as epitope or antigen spreading whereby $\mathrm{T}$ cells recognize a family of antigens that have diversified from the original parental epitope (12). This explains why HLA-matched unrelated donors are at a higher risk for GVHD than HLAmatched sibling donors (13), since the frequency of genetic disparity for individual miHA is generally two-fold higher (10, 14). The other type of antigen recognition by the donor $\mathrm{T}$ cell is within the complex of mismatched MHC and a nonpolymorphic peptide. Naive $\mathrm{T}$ cells have been educated in the thymus to react a peptide loaded on self MHC. Therefore, donor $\mathrm{T}$ cells are not designed to react to antigen presented by a mismatched MHC. However, a scenario can occur whereby the molecular complex of a peptide and mismatched MHC is structurally sufficiently similar to that of another peptide and matched MHC to activate a donor T cell. This type of donor T cell antigen recognition happens in MHC-mismatched transplantation and is known as molecular mimicry (15). This process explains why increased numbers of mismatched MHC loci (6/8, 7/8 vs 8/8 HLA match) significantly increases GVHD and decreases overall survival regardless of the underlying type of malignant disease (16). Thirdly, the pathophysiology and manifestations of GVHD seen after transplant should recapitulate those in clinical GVHD. The pathways of antigen presentation leading to GVHD are highly promiscuous in xenograft systems where immune deficient mice (and their APC) stimulate a human $T$ cell response, such that their usefulness in studying the mechanisms of GVHD is somewhat limited.

Many non-transgenic donor and host combinations have been well established for the study of GVHD. These include MHC mismatched or MHC-matched but miHA-mismatched models which are typically dominated by MHC-I or II dependent GVHD that is largely strain dependent. We direct the reader to excellent reviews on the subject of these non-transgenic models (17). Here we focus on antigen-specific models of GVHD.

\section{ALLOANTIGEN PRESENTATION IN MODELS OF GVHD TARGETING MINOR HISTOCOMPATIBILITY ANTIGENS}

In MHC matched systems, the cognate recognition of antigen by a mature, thymically educated, donor T cell requires the TCR to interact with host polymorphic peptide (miHA) presented by a HLA molecule common to donor and host. Defined human miHAs have been the subject of recent reviews $(10,11,14)$. While the most common molecular mechanism generating miHAs is single nucleotide polymorphisms (SNPs) within gene exons that modify peptide binding to MHC or TCR, other mechanisms such as altered protein transport/processing or transcription can also cause the generation of dramatically new epitopes $(10,11)$. The expression of ovalbumin (Ova) in BMT recipients under control of ubiquitous (e.g. $\beta$-actin) promoters may mimic the latter setting. Since ova is not expressed by normal mice, transgenic ova production by recipient mice can be a dominant antigen to $\mathrm{CD}^{+}$and $\mathrm{CD} 8^{+} \mathrm{T}$ cells $(18,19)$. When ova expression is limited to specific cell types such as hematopoietic cells $(20,21)$ or leukemic cells $(22)$, it may mimic hematopoiesis-specific or leukemia-specific miHA. Given that these hematopoietic- or leukemia-restricted miHAs have attracted attention as targets for clinical TCR transgenic T cell therapy $(23,24)$, these antigen model systems can be useful in understanding immunity within these contexts. In regard to ova, extensive tool reagents are available. Ova peptide-specific $\mathrm{CD} 4^{+}$ and $\mathrm{CD}^{+}$TCR transgenic mice (OT-II, DO11.10 and OT-I mice) can be utilized as a source of donor T cells, whereby short term $\mathrm{T}$ cell activation and expansion can be used to quantify antigen presentation $(18,19,25)$. Ova peptide-MHC tetramers can be utilized to detect peptide-specific $\mathrm{T}$ cells within polyclonal $\mathrm{T}$ cells (26) and the monoclonal antibody (25-D1.16) can also quantify ova-peptide loaded within MHC -I to quantify direct antigen presentation (27). Many foreign peptide/proteins other than ova, such as virus-derived proteins, can also be exploited in a similar fashion (Table 1).

Similarly, strain-specific models of endogenous antigen also exist. H60 protein, a ligand for NKG2D, is expressed by hematopoietic cells but not parenchyma cells in a strainspecific manner. H60 is expressed by BALB.B mice but not C57Bl6 (B6) nor C3H.SW mice, and these three stains are all MHC-matched $\left(\mathrm{H}-2^{\mathrm{b}}\right)$ but miHA disparate. Recently, H60 transduction has been undertaken into B6-background leukemia or recipient mice and $\mathrm{H} 60$ peptide- $\mathrm{H} 2 \mathrm{~K}^{\mathrm{b}}$ tetramers used to detect responding $\mathrm{CD}^{+} \mathrm{T}$ cells in combination with MHC-I deficient mice $\left(\mathrm{H}-2 \mathrm{~K}^{\mathrm{b}-{ }^{-}}\right)$to demonstrate how defects in leukemia antigen presentation promote exhaustion of donor $\mathrm{T}$ cells and ineffective GVL (42) (Table 1).

HLA molecules are highly polymorphic (43). Since HLAmismatched transplants (including haplo-identical transplantation) are all semi HLA-matched, mismatched HLAderived peptides can be presented by another shared HLA. To mimic this scenario, TEa transgenic TCR (V $\alpha 2 / \mathrm{V} \beta 6) \mathrm{T}$ cells and YAe antibody recognize the same complex of mismatched MHCderived peptide presented within MHC-II (E $052-68$ peptide and 
TABLE 1 | Minor antigens within MHC matched systems and antigen-specific TCR transgenic T cells (top), peptide-MHC tetramer to detect antigen-specific T cells (middle) and antibodies to quantify antigen-MHC complexes (bottom).

\begin{tabular}{|c|c|c|c|c|c|}
\hline Ag protein & Ag peptide & MHC-restriction & TCR-Transgenic mouse & \multicolumn{2}{|c|}{ Reference } \\
\hline Ova albumin & $\begin{array}{l}\text { OVA257-264 } \\
\text { (SIINFEKL) }\end{array}$ & $\mathrm{H}-2 \mathrm{~K}^{\mathrm{b}}$ & OT-I & \multicolumn{2}{|c|}{ (19) } \\
\hline $\mathrm{H} 60$ & LTFNYRNL & $\mathrm{H}-2 \mathrm{~K}^{\mathrm{b}}$ & J15 & \multicolumn{2}{|c|}{$(28,29)$} \\
\hline $\mathrm{H}-\mathrm{Y}$, Uty gene & WMHHNMDLI & $H-2 D^{b}$ & MataHari & \multicolumn{2}{|c|}{ (30) } \\
\hline $\mathrm{H}-\mathrm{Y}$ & unknown & $H-2 D^{b}$ & HY-TCR & \multicolumn{2}{|c|}{$(31)$} \\
\hline $\mathrm{H}-\mathrm{Y}$ & unknown & $1-A^{b}$ & Rachel & \multicolumn{2}{|c|}{ (32) } \\
\hline H-Y, Dby gene & NAGFNSNRANSSRSS & $1-A^{b}$ & Marilyn & \multicolumn{2}{|c|}{$(33,34)$} \\
\hline I-E & $\mathrm{E} \alpha 52-68$ & $1-A^{b}$ & TEa & \multicolumn{2}{|c|}{ (35) } \\
\hline Ova albumin & OVA323-339 & $1-A^{b}$ & OT-॥ & \multicolumn{2}{|c|}{ (18) } \\
\hline Ova albumin & $\begin{array}{l}\text { OVA323-339, } \\
\text { 327-333, 328-338 }\end{array}$ & $1-A^{d}$ & D011.10 & \multicolumn{2}{|c|}{$(25)$} \\
\hline Ag protein & Ag peptide & MHC-restriction & TCR Detection tetramer & \multicolumn{2}{|c|}{ Reference } \\
\hline $\mathrm{H} 60$ & LTFNYRNL & $\mathrm{H}-2 \mathrm{~K}^{\mathrm{b}}$ & $\mathrm{H} 6 / \mathrm{H}-2 \mathrm{~K}^{\mathrm{b}}$ tetramer & \multicolumn{2}{|c|}{$(36,37)$} \\
\hline $\mathrm{H}-\mathrm{Y}$, Uty gene & WMHHNMDLI & $H-2 D^{b}$ & $\mathrm{HY}-\mathrm{Uty} / \mathrm{H}-2 \mathrm{D}^{\mathrm{b}}$ tetramer & \multicolumn{2}{|c|}{ (37) } \\
\hline Ova albumin & OVA323-339 & $1-A^{b}$ & OVA323-339/I- $A^{b}$ tetramer & \multicolumn{2}{|c|}{ (38) } \\
\hline Ova albumin & OVA323-339 & $1-A^{d}$ & OVA323-339/I-A $A^{d}$ tetramer & \multicolumn{2}{|c|}{$(26)$} \\
\hline Ag protein & Ag peptide & MHC-restriction & Antibody reactivity & Clone & Reference \\
\hline Ova albumin & OVA257-264 (SIINFEKL) & $\mathrm{H}-2 \mathrm{~K}^{\mathrm{b}}$ & Against SIINFEKL bound to $\mathrm{H}-2 \mathrm{~K}^{\mathrm{b}}$ & 25-D1.16 & $(27)$ \\
\hline I-Ea chain & $\mathrm{E} \alpha 52-68$ & $1-A^{b}$ & $\begin{array}{l}\text { Against E } \alpha 52-68 \\
\text { peptide bound to I-A }\end{array}$ & $Y-A e$ & $(39,40)$ \\
\hline hen egg lysozyme (HEL) & HEL-derived peptide (HEL48-62) & $1-A^{k}$ & Against HEL peptide (residue 48-62) bound to I- $A^{k}$ & AW3.18 & $(41)$ \\
\hline
\end{tabular}

Superscript letters indicate MHC types.

I- $A^{b}$ respectively) $(35,39,40)$. B6 mice lack I-E $\alpha$ chain, hence, do not express I-E, a MHC-II locus, whereas many other strains express the I-E $\alpha$ chain. Thus the E $\alpha 52-68$ peptide derived from the I-E $\alpha$ chain of relevant recipient strains can stimulate TEa T cells and bind to the YAe antibody in an $\mathrm{I}^{-} \mathrm{A}^{\mathrm{b}}$-restricted manner. To our knowledge, YAe, the aforementioned 25-D1.16 and AW3.18 which binds to hen egg lysozyme (HEL) peptide loaded on $\mathrm{I}-\mathrm{A}^{\mathrm{k}}$, are the only antibodies that bind to specific peptide-MHC complexes that are commercially available (Table 1). They are highly useful tools for the quantification of antigen presentation. Thus while antigen-specific $\mathrm{T}$ cell expansion detected by tetramer or as TCR transgenic $\mathrm{T}$ cell expansion reflects overall antigen presentation, these antibodies allow direct quantification of antigen presentation within individual APC subsets that are distinguishable by flow cytometry (e.g. donor cell $v s$. host cells, dendritic cell subsets $v s$ macrophages, and within different organs) (44).

The transplantation of a female-derived graft into a male recipient is a known risk factor for GVHD (13). Multiple H-Y antigens encoded by Y-chromosome genes have been identified (e.g. SMCY, UTY, DBY, DEFRY) and reactive T cell clones have been isolated from female transplant recipients rejecting male grafts and male recipients transplanted with female grafts (4548). Multiple murine TCR clones and TCR transgenic lines reactive to $\mathrm{H}-\mathrm{Y}$ antigens (e.g. UTY, DBY) have been generated on a B6 background (Table 1) (30-34). In addition to their clear clinical relevance, these systems allow the use of male B6 mice from most transgenic and mutant strains (e.g. MHC-deficient recipients) to delineate mechanistic pathways of antigen presentation. As such, these systems provide powerful tools for the study of GVHD. The incorporation of reporter constructs such as luciferase into these TCR transgenic systems allows detailed and tissue specific compartmentalization of antigen presentation $(20,44,49,50)$.

\section{ALLOANTIGEN PRESENTATION IN MODELS CHARACTERIZED BY MOLECULAR MIMICRY}

It is well established in studies some 50 years ago that $1-10 \%$ peripheral $\mathrm{T}$ cells are reactive to non-self (mismatched) $\mathrm{MHC}$, although the frequency of $\mathrm{T}$ cells that can respond to self (matched) MHC-expressing cell loaded with foreign Ag is likely at least 100-fold lower $(51,52)$. However, the mechanism underlying the high degree of clonal $\mathrm{T}$ cell alloreactivity to MHC-mismatched antigen has only recently been elucidated (53, 54). For decades there was a controversy over whether a $\mathrm{T}$ cell reacts to peptide-alloMHC (mismatched $\mathrm{MHC}$ ) complexes in a peptide-centric or MHC-centric manner. In the former, TCR primarily interacts with the peptide rather than mismatched MHC, whereas the latter anticipates that a TCR primarily recognizes structural determinants on the (mismatched) MHC structure $(15,54,55)$. The dispute has now been settled in favor of reactivity against the hybrid of peptide- and $\mathrm{MHC}$-centric hypothesis. A TCR can thus recognize peptide-loaded allogeneic MHC 1) in docking modes disparate to those that are germlineencoded following thymic education (55) and 2) in the germlineencoded mode via molecular mimicry whereby the TCR binds to very similar structure formed by a foreign peptide presented on self-MHC and an endogenous peptide presented on allogeneic MHC (15). Both theories potentially explain allogeneic MHC reactivity. The former scenario of disparate docking modes has been demonstrated for $2 \mathrm{C}$ TCR $\left(\mathrm{H}-2 \mathrm{~K}^{\mathrm{b}}\right) \mathrm{T}$ cells which react to a 
self-peptide (dEV8, also known as Ndufa4 $4_{54-61}$ ) derived from enzyme NADH-ubiquinone oxidoreductase, loaded on $\mathrm{H}-2 \mathrm{~K}^{\mathrm{b}}$ $(56,57)$ and indeed this clone has been used to study positive selection in the thymus $(57,58)$. This scenario is of questionable relevance to transplant immunology where non-self-reactive mature $\mathrm{T}$ cells recognize MHC-mismatched cells. In the latter setting, what is striking is the demonstration that a TCR clone (LC13) recognizing Epstein-Barr virus (EBV)-derived peptide on self-MHC (HLA-B $\left.{ }^{\star} 0801\right)$ can recognize self-peptide on some allogeneic MHCs (HLA-B ${ }^{\star} 4402$ and $B^{\star} 4405$, but not $B^{\star} 4403$ ) due to a similar conformation (molecular mimicry) after TCR ligation (15). HLA-B ${ }^{\star} 4402$ or $\mathrm{B}^{\star} 4405$ transfected HLA class Ideficient $(\mathrm{C} 1 \mathrm{R})$ cell lines $\left(\mathrm{C} 1 \mathrm{R}-\mathrm{B}^{\star} 4402\right.$ and $\left.\mathrm{C} 1 \mathrm{R}-\mathrm{B}^{\star} 4405\right)$ but not a $\mathrm{B}^{\star} 0801$ transfected one $\left(\mathrm{C} 1 \mathrm{R}-\mathrm{B}^{\star} 0801\right)$ can activate $\mathrm{LC} 13$, indicating that endogenous antigens (e.g. ATP-binding cassette protein) can stimulate TCR clones when they are presented by some but not all allogeneic HLA molecules. Vice versa, an EBVpeptide can stimulate LC13 when it is presented by self-HLA $\left(\mathrm{B}^{\star} 0801\right)$ but not allogeneic HLA $\left(\mathrm{B}^{\star} 4405\right)$. Indeed, healthy individuals that are heterozygous for HLA-B ${ }^{\star} 0801$ and $\mathrm{B}^{\star} 4402$ do not possess this dominant LC13 TCR clonotype, demonstrating this clonotype has been clonally deleted due to potential selfreactiveness, and instead, they generate alternative clonotypes reactive to the same viral epitope (59). This suggests a phenomenon whereby one TCR clone reactive to a foreign peptide also responds to endogenous peptides presented by other MHC molecules within one individual. In the MHC-mismatched allogeneic transplant a donor TCR repertoire will encounter new MHC molecules, and be activated by host mismatched MHC molecules loaded with endogenous (non-polymorphic) peptides [a schematic illustration depicting the different modes of alloantigen presentation has been published previously (5)].

To study alloantigen presentation by a mismatched $\mathrm{MHC}$ molecule, MHC-mismatched models can be chosen [e.g. B6 (H$\left.\left.2^{\mathrm{b}}\right) \rightarrow \mathrm{BALB} / \mathrm{c}\left(\mathrm{H}-2^{\mathrm{d}}\right)\right]$. MHC-partial mismatched or haplomismatched models include the possibility that matched MHC molecules present miHAs derived from mismatched $\mathrm{MHC}$ molecules. In this context, B6-background Bm1 (MHC-I mutation resulting in amino acid substitution) and $\mathrm{Bm} 12$ (MHC-II mutation resulting in amino acid substitution) mice are useful (Table 2). When either $\mathrm{CD}^{+}{ }^{+}$or $\mathrm{CD} 8^{+} \mathrm{T}$ cells and BM cells from wild-type $\mathrm{B} 6$ were injected into lethally irradiated $\mathrm{Bm} 1$ and $\mathrm{Bm} 12$ recipients, donor $\mathrm{CD} 4^{+} \mathrm{T}$ cells induced lethal GVHD in only $\mathrm{Bm} 12$ recipients, and donor $\mathrm{CD}^{+} \mathrm{T}$ cells did so only in $\mathrm{Bm} 1$ recipients (67). When $\mathrm{Bm} 12 \mathrm{~T}$ cells were transplanted in MHC-II deficient or wild-type B6 mice, serum IFN- $\gamma$ was elevated in wild-type recipients but not in MHC-II deficient recipients (68). Similarly, in-vitro culture (mixed lymphocyte reaction) demonstrated that $\mathrm{B} 6 \mathrm{CD}^{+} \mathrm{T}$ cells proliferate in response to $\mathrm{Bm} 12$ cells but not $\mathrm{Bm} 1$ or $\mathrm{B} 6$ (self) cells, and $\mathrm{B} 6$ $\mathrm{CD}^{+} \mathrm{T}$ cells proliferate to $\mathrm{Bm} 1$ cells but not $\mathrm{Bm} 12$ or $\mathrm{B} 6$ cells (67). Despite the potential possibility that $\mathrm{Bm} 1$ and $\mathrm{Bm} 12$ mutation themselves serve as miHAs on conserved MHC-I or II molecules, this scenario would generate both $\mathrm{CD} 4^{+}$and $\mathrm{CD} 8^{+}$ $\mathrm{T}$ cell responses, and so can be discounted. Instead, they suggest that both mutated MHC-I and II, $\mathrm{H} 2-\mathrm{K}^{\mathrm{bm} 1}$ and $\mathrm{H} 2-\mathrm{Ab} 1^{\mathrm{bm} 12}$, are loaded with endogenous peptides that bind $\mathrm{B} 6 \mathrm{CD} 8^{+}$and $\mathrm{CD} 4^{+}$ TCR repertoires, respectively. There are other many similar MHC-I-mutated mice, most of which have mutation in the $\mathrm{H}$ $2 \mathrm{~K}$ locus (e.g. bm3 and bm8) $(69,70)$, while MHC-II-mutated strains are limited to Bm12 (Table 2).

In contrast to studies utilizing specific mutations within MHC class I or II, TCR transgenic T cells which react to specific MHC disparities have also been exploited. In addition to the previously described 2C TCR transgenic $\mathrm{CD}^{+} \mathrm{T}$ cells, 4C TCR transgenic $\mathrm{CD}^{+} \mathrm{T}$ cells from $\mathrm{B} 6$ mice respond to an endogenous and ubiquitously expressed mouse non-polymorphic peptide presented on I-A ${ }^{\mathrm{d}}(66)$.

\section{ANTIGEN PRESENTATION IN XENOGRAFT TRANSPLANT MODELS}

There has been a controversy in regard to how faithfully inbred murine allogeneic transplant models recapitulate GVHD in outbred humans. A number of studies have thus been conducted in xenogeneic transplant systems whereby human hematopoietic cells [most commonly peripheral blood mononuclear cells (PBMC)] are transplanted into severely immunodeficient mice (e.g. NSG, NRG, NOG mice) (71). PBMC is predominantly composed of lymphocytes, although APC including monocytes and dendritic cells are included. However, there is no hematopoietic progenitor or stem cell components, hence, the differentiation of human APC is not sustained. There is also a question as to whether human $\mathrm{T}$ cells can appropriately recognize murine $\mathrm{MHC}$ and if not whether these systems are indeed clinically relevant. In addition, there are three other major constraints to the interpretation of xenogeneic transplant systems. Firstly, it does not phenocopy clinical GVHD. While clinical acute GVHD typically targets the skin, liver and gastrointestinal (GI) tract and the intestinal disease usually determines lethality, the skin and GI tract display only very mild changes after xenogeneic transplant $(72,73)$. The major pathogenic manifestations of GVHD in xenogeneic transplant models are predominantly observed in the liver and lung and give rise to lethality. Second, since human cell engraftment is limited and predominantly of $\mathrm{T}$ cells after PBMC are transplanted, the GVHD induced is unlikely to recapitulate the spectrum seen following full $\mathrm{T}$ and myeloid cell engraftment seen in species-specific systems. Finally, it is unclear the role that mouse anti-human graft rejection (e.g. by myeloid cells) plays in the spectrum of GVHD seen in these systems $(72,74,75)$.

It has been demonstrated that murine MHC-I and II molecules stimulate human $\mathrm{T}$ cells after human PBMC injection into NSG mice $(73,75,76)$. When recipient NSG mice lack murine MHC-I expression, disease lethality and the frequency of human $\mathrm{CD}^{+} \mathrm{T}$ cells in the recipient are reduced. The presence or absence of murine MHC-II expression is less important in isolation since its deficiency does not attenuate lethality (75). Although these data suggest that human $\mathrm{T}$ cells can react to murine $\mathrm{MHC}$, human $\mathrm{T}$ cells primarily respond to 
TABLE 2 | Antigen presentation within mismatched MHC. miHA matched.

\begin{tabular}{|c|c|c|c|c|c|c|}
\hline $\begin{array}{l}\text { Mismatched } \\
\text { MHC }\end{array}$ & $\begin{array}{c}\text { MHC } \\
\text { mutation }\end{array}$ & Known peptide/MHC complex & $\begin{array}{c}\text { T cell's } \\
\text { self-MHC }\end{array}$ & $\begin{array}{l}\text { Reactive TCR } \\
\text { Detection by }\end{array}$ & $\mathrm{T}$ cell from & Reference \\
\hline $\mathrm{H}-2 \mathrm{~K}^{\mathrm{bm} 1}$ & $\begin{array}{l}7 \\
\text { nucleotides }\end{array}$ & & $\mathrm{H}-2 \mathrm{~K}^{\mathrm{b}}$ & & $\begin{array}{l}\text { Multiple clones from } \\
\text { C57BL6 }\end{array}$ & $(60)$ \\
\hline $\mathrm{H} 2-\mathrm{Ab} 1^{\mathrm{bm} 12}$ & $\begin{array}{l}3 \\
\text { nucleotides }\end{array}$ & & $\mathrm{H} 2-\mathrm{Ab} 1^{\mathrm{b}}$ & & $\begin{array}{l}\text { Multiple clones from } \\
\text { C57BL6 }\end{array}$ & $(61,62)$ \\
\hline $\mathrm{H}-2 \mathrm{~L}^{\mathrm{d}}$ & & 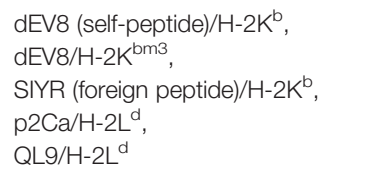 & $\mathrm{H}-2^{\mathrm{b}}$ & $\begin{array}{l}\text { 1B2 (anti-2C TCR } \\
\mathrm{mAb} \text { ) }\end{array}$ & $\begin{array}{l}\text { 2C TCR transgenic } \\
\text { mice }\end{array}$ & $\begin{array}{l}\text { Originally BALB.B CD8 }{ }^{+} \mathrm{T} \\
\text { cells when immunized P815 } \\
\text { (DBA/2 mastocytoma line) } \\
\text { and BALB/c splenocytes } \\
\text { (63-65). }\end{array}$ \\
\hline $\begin{array}{l}H_{2}-I^{d} A^{d} \\
\left(I-A^{d}\right)\end{array}$ & & $\begin{array}{l}\text { unknown non-polymorphic mouse } \\
\text { peptide/l- } A^{d}\end{array}$ & $\begin{array}{l}\mathrm{H} 2-\mathrm{Ab} 1 \\
\left(1-\mathrm{A}^{\mathrm{b}}\right)\end{array}$ & & $\begin{array}{l}\text { 4C TCR transgenic } \\
\text { mice }\end{array}$ & $(66)$ \\
\hline
\end{tabular}

Superscript letters indicate MHC types.

human MHC (HLA) molecules rather than murine MHC in vitro $(77,78)$. Therefore, multiple immunodeficient mouse strains expressing HLA class I (e.g. HLA-A2) and class II (e.g. HLADR1 or DR4) have been developed $(73,79,80)$. These mice have been demonstrated to develop HLA-restricted anti-virus human $\mathrm{T}$ cell clones after human HSC transplantation $(79,80)$, suggesting the transgenic human HLA indeed preferentially invoke human TCR responses. However, physiological upregulation of MHC and antigen presentation therein are not assured. While multiple cytokines (i.e. interferon (IFN) $\gamma$, interleukin (IL)-4, IL-6, IL-10, IFN- $\alpha / \beta$ and tissue necrosis factor) and glucocorticoids modulate MHC-I and II expression $(81,82)$ and many are secreted by human $\mathrm{T}$ cells after xenogeneic transplantation, the majority are not cross-reactive with the relevant murine receptors.

The presence of both murine and human MHC in these humanized transgenic systems likely creates promiscuous antigen recognition. NSG mice with intact murine MHC (H-2) and transgenic HLA- $\mathrm{A}^{*} 0201$ expression develop accelerated lethality after transplantation with human PBMC, but equivalent histopathology (relative to HLA- ${ }^{\star} 0201$-negative NSG mice) (83). In vitro assays demonstrate that multiple human $\mathrm{CD}^{+}$and $\mathrm{CD}^{+} \mathrm{T}$ cell clones are reactive to both murine MHC-I and II (84). In addition, highly aberrant $\mathrm{CD} 4^{+} \mathrm{CD} 8^{+} \mathrm{T}$ cell expansion within tissue has been seen after xenogeneic but not clinical transplantation and this likely reflects non-physiological antigen presentation (85). Thus while the mechanism by which human TCR can respond to a murine peptide-MHC complex is an intriguing question, the reality is that disordered antigen presentation is a serious confounding factor.

Another possible approach of in vivo model is to utilize the mice which have already been reconstituted by human hematopoiesis. To achieve human hematopoietic APC engraftment, the transplant of human bone marrow or cord blood (CB) derived $\mathrm{CD} 34^{+}$HSC into immune deficient mice is promising $(74,86,87)$. These methods achieved stable and high level of human cell engraftment in the BM and spleen (> 50\%) but with a low frequency of $\mathrm{CD} 33^{+}$or $\mathrm{CD} 14^{+}$human myeloid cells. Human CB-derived HSC injection into newborn NSG mice demonstrated the presence of human HLA-DR ${ }^{+} \mathrm{CD} 11 \mathrm{c}^{+}$cell in the spleen three months after transplant (86). NSG-SGM3
(NSGS) mice which express additional transgenic genes for human IL-3, GM-CSF and SCF and MISTRG mice which express human IL-3, GM-CSF, M-CSF, thrombopoietin and SIRP $\alpha$, significantly improve human myeloid cell reconstitution (88-90). Nevertheless, the issue of concurrent murine MHC expression in these systems remains a confounding variable.

\section{CONCLUSIONS}

The advantage of fully murine models that permit delineation of antigen-specific responses includes the ability to spatially and temporally track antigen presentation and resultant $\mathrm{T}$ cell responses in vivo, coupled with extensive availability of mutant and transgenic strains to delineate mechanisms of disease. Nevertheless, it remains important to validate these results with polyclonal $\mathrm{T}$ cells in MHC-mismatched or miHAmismatched transplant models. The use of xenograft models are increasingly important for the examination of immune independent therapeutic effects (e.g. the effect of a drug on a human leukemia in vivo) or human-human cellular interactions in vivo (e.g. a human CAR $\mathrm{T}$ cell or TCR transgenic $\mathrm{T}$ cell response against a human leukemia). In contrast, the species mismatch inherent in these systems at the APC-T cell interface makes them more problematic as a robust preclinical transplant platform. Hence, the use of xenogeneic models for GVHD/GVL studies ought to be used cautiously, sparingly, and ideally as an adjunct to appropriate allogeneic models.

\section{AUTHOR CONTRIBUTIONS}

All authors listed have made a substantial, direct, and intellectual contribution to the work and approved it for publication.

\section{FUNDING}

This work was supported by a research grant from the National Heart, Lung, and Blood Institute of the NIH (R01HL148164), United States. 


\section{REFERENCES}

1. Weiden PL, Flournoy N, Thomas ED, Prentice R, Fefer A, Buckner CD, et al. Antileukemic Effect of Graft-Versus-Host Disease in Human Recipients of Allogeneic-Marrow Grafts. N Engl J Med (1979) 300:1068-73. doi: 10.1056/ NEJM197905103001902

2. Marmont AM, Horowitz MM, Gale RP, Sobocinski K, Ash RC, van Bekkum DW, et al. T-Cell Depletion of HLA-Identical Transplants in Leukemia. Blood (1991) 78:2120-30. doi: 10.1182/blood.V78.8.2120.2120

3. Horowitz MM, Gale RP, Sondel PM, Goldman JM, Kersey J, Kolb HJ, et al. Graft-Versus-Leukemia Reactions After Bone Marrow Transplantation. Blood (1990) 75:555-62. doi: 10.1182/blood.V75.3.555.555

4. Wagner JE, Thompson JS, Carter SL, Kernan NA, Unrelated Donor Marrow Transplantation T. Effect of Graft-Versus-Host Disease Prophylaxis on 3Year Disease-Free Survival in Recipients of Unrelated Donor Bone Marrow (T-Cell Depletion Trial): A Multi-Centre, Randomised Phase II-III Trial. Lancet (2005) 366:733-41. doi: 10.1016/S0140-6736(05)66996-6

5. Koyama M, Hill GR. Alloantigen Presentation and Graft-Versus-Host Disease: Fuel for the Fire. Blood (2016) 127:2963-70. doi: 10.1182/blood2016-02-697250

6. Koyama M, Hill GR. The Primacy of Gastrointestinal Tract AntigenPresenting Cells in Lethal Graft-Versus-Host Disease. Blood (2019) 134:2139-48. doi: 10.1182/blood.2019000823

7. Matte CC, Liu J, Cormier J, Anderson BE, Athanasiadis I, Jain D, et al. Donor APCs Are Required for Maximal GVHD But Not for GVL. Nat Med (2004) 10:987-92. doi: 10.1038/nm1089

8. Reddy P, Maeda Y, Liu C, Krijanovski OI, Korngold R, Ferrara JL. A Crucial Role for Antigen-Presenting Cells and Alloantigen Expression in Graft-VersusLeukemia Responses. Nat Med (2005) 11:1244-9. doi: 10.1038/nm1309

9. Matte-Martone C, Venkatesan S, Tan HS, Athanasiadis I, Chang J, Pavisic J, et al. Graft-Versus-Leukemia (GVL) Against Mouse Blast-Crisis Chronic Myelogenous Leukemia (BC-CML) and Chronic-Phase Chronic Myelogenous Leukemia (CP-CML): Shared Mechanisms of T Cell Killing, But Programmed Death Ligands Render CP-CML and Not BC-CML GVL Resistant. J Immunol (2011) 187:1653-63. doi: 10.4049/jimmunol.1100311

10. Bleakley M, Riddell SR. Exploiting T Cells Specific for Human Minor Histocompatibility Antigens for Therapy of Leukemia. Immunol Cell Biol (2011) 89:396-407. doi: 10.1038/icb.2010.124

11. Griffioen M, van Bergen CA, Falkenburg JH. Autosomal Minor Histocompatibility Antigens: How Genetic Variants Create Diversity in Immune Targets. Front Immunol (2016) 7:100. doi: 10.3389/fimmu.2016.00100

12. Vanderlugt CL, Miller SD. Epitope Spreading in Immune-Mediated Diseases: Implications for Immunotherapy. Nat Rev Immunol (2002) 2:85-95. doi: $10.1038 /$ nri724

13. Flowers ME, Inamoto Y, Carpenter PA, Lee SJ, Kiem HP, Petersdorf EW, et al. Comparative Analysis of Risk Factors for Acute Graft-Versus-Host Disease and for Chronic Graft-Versus-Host Disease According to National Institutes of Health Consensus Criteria. Blood (2011) 117:3214-9. doi: 10.1182/blood2010-08-302109

14. Spierings E. Minor Histocompatibility Antigens: Past, Present, and Future. Tissue Antigens (2014) 84:374-60. doi: 10.1111/tan.12445

15. Macdonald WA, Chen Z, Gras S, Archbold JK, Tynan FE, Clements CS, et al. T Cell Allorecognition via Molecular Mimicry. Immunity (2009) 31:897-908. doi: 10.1016/j.immuni.2009.09.025

16. Lee SJ, Klein J, Haagenson M, Baxter-Lowe LA, Confer DL, Eapen M, et al. High-Resolution Donor-Recipient HLA Matching Contributes to the Success of Unrelated Donor Marrow Transplantation. Blood (2007) 110:4576-83. doi: 10.1182/blood-2007-06-097386

17. Reddy P, Negrin R, Hill GR. Mouse Models of Bone Marrow Transplantation. Biol Blood Marrow Transplant (2008) 14:129-35. doi: 10.1016/j.bbmt. 2007.10.021

18. Barnden MJ, Allison J, Heath WR, Carbone FR. Defective TCR Expression in Transgenic Mice Constructed Using cDNA-Based Alpha- and Beta-Chain Genes Under the Control of Heterologous Regulatory Elements. Immunol Cell Biol (1998) 76:34-40. doi: 10.1046/j.1440-1711.1998.00709.x

19. Hogquist KA, Jameson SC, Heath WR, Howard JL, Bevan MJ, Carbone FR. T Cell Receptor Antagonist Peptides Induce Positive Selection. Cell (1994) 76:17-27. doi: 10.1016/0092-8674(94)90169-4
20. Koyama M, Kuns RD, Olver SD, Raffelt NC, Wilson YA, Don AL, et al. Recipient Nonhematopoietic Antigen-Presenting Cells Are Sufficient to Induce Lethal Acute Graft-Versus-Host Disease. Nat Med (2012) 18:135-42. doi: $10.1038 / \mathrm{nm} .2597$

21. Coleman MA, Bridge JA, Lane SW, Dixon CM, Hill GR, Wells JW, et al. Tolerance Induction With Gene-Modified Stem Cells and ImmunePreserving Conditioning in Primed Mice: Restricting Antigen to Differentiated Antigen-Presenting Cells Permits Efficacy. Blood (2013) 121:1049-58. doi: 10.1182/blood-2012-06-434100

22. Hasegawa K, Tanaka S, Fujiki F, Morimoto S, Nakajima H, Tatsumi N, et al. An Immunocompetent Mouse Model for MLL/AF9 Leukemia Reveals the Potential of Spontaneous Cytotoxic T-Cell Response to an Antigen Expressed in Leukemia Cells. PloS One (2015) 10:e0144594. doi: 10.1371/journal.pone.0144594

23. Dossa RG, Cunningham T, Sommermeyer D, Medina-Rodriguez I, Biernacki MA, Foster K, et al. Development of T-Cell Immunotherapy for Hematopoietic Stem Cell Transplantation Recipients at Risk of Leukemia Relapse. Blood (2018) 131:108-20. doi: 10.1182/blood-2017-07-791608

24. Chapuis AG, Egan DN, Bar M, Schmitt TM, McAfee MS, Paulson KG, et al. T Cell Receptor Gene Therapy Targeting WT1 Prevents Acute Myeloid Leukemia Relapse Post-Transplant. Nat Med (2019) 25:1064-72. doi: 10.1038/s41591-019-0472-9

25. Robertson JM, Jensen PE, Evavold BD. DO11.10 and OT-II T Cells Recognize a C-Terminal Ovalbumin 323-339 Epitope. J Immunol (2000) 164:4706-12. doi: 10.4049/jimmunol.164.9.4706

26. Landais E, Romagnoli PA, Corper AL, Shires J, Altman JD, Wilson IA, et al. New Design of MHC Class II Tetramers to Accommodate Fundamental Principles of Antigen Presentation. J Immunol (2009) 183:7949-57. doi: 10.4049/jimmunol.0902493

27. Porgador A, Yewdell JW, Deng Y, Bennink JR, Germain RN. Localization, Quantitation, and in Situ Detection of Specific Peptide-MHC Class I Complexes Using a Monoclonal Antibody. Immunity (1997) 6:715-26. doi: 10.1016/S1074-7613(00)80447-1

28. Jeon JY, Jung KM, Chang J, Choi EY. Characterization of CTL Clones Specific for Single Antigen, H60 Minor Histocompatibility Antigen. Immune Netw (2011) 11:100-6. doi: 10.4110/in.2011.11.2.100

29. Ju JM, Kim MB, Ryu SJ, Kim JY, Chang J, Choi EY. Selection of Thymocytes Expressing Transgenic TCR Specific for a Minor Histocompatibility Antigen, H60. Immune Netw (2015) 15:222-31. doi: 10.4110/in.2015.15.5.222

30. Valujskikh A, Lantz O, Celli S, Matzinger P, Heeger PS. Cross-Primed CD8(+) T Cells Mediate Graft Rejection via a Distinct Effector Pathway. Nat Immunol (2002) 3:844-51. doi: 10.1038/ni831

31. von Boehmer H. Developmental Biology of $\mathrm{T}$ Cells in $\mathrm{T}$ Cell-Receptor Transgenic Mice. Annu Rev Immunol (1990) 8:531-56. doi: 10.1146/ annurev.iy.08.040190.002531

32. Grandjean I, Duban L, Bonney EA, Corcuff E, Di Santo JP, Matzinger P, et al. Are Major Histocompatibility Complex Molecules Involved in the Survival of Naive CD4+ T Cells? J Exp Med (2003) 198:1089-102. doi: 10.1084/ jem.20030963

33. Lantz O, Grandjean I, Matzinger P, Di Santo JP. Gamma Chain Required for Naive CD4+ T Cell Survival But Not for Antigen Proliferation. Nat Immunol (2000) 1:54-8. doi: 10.1038/76917

34. Scott D, Addey C, Ellis P, James E, Mitchell MJ, Saut N, et al. Dendritic Cells Permit Identification of Genes Encoding MHC Class II-Restricted Epitopes of Transplantation Antigens. Immunity (2000) 12:711-20. doi: 10.1016/S10747613(00)80221-6

35. Grubin CE, Kovats S, deRoos P, Rudensky AY. Deficient Positive Selection of CD4 T Cells in Mice Displaying Altered Repertoires of MHC Class II-Bound Self-Peptides. Immunity (1997) 7:197-208. doi: 10.1016/S1074-7613(00)80523-3

36. Malarkannan S, Shih PP, Eden PA, Horng T, Zuberi AR, Christianson G, et al. The Molecular and Functional Characterization of a Dominant Minor $\mathrm{H}$ Antigen, H60. J Immunol (1998) 161:3501-9.

37. Choi EY, Yoshimura Y, Christianson GJ, Sproule TJ, Malarkannan S, Shastri $\mathrm{N}$, et al. Quantitative Analysis of the Immune Response to Mouse non-MHC Transplantation Antigens In Vivo: The H60 Histocompatibility Antigen Dominates Over All Others. J Immunol (2001) 166:4370-9. doi: 10.4049/ jimmunol.166.7.4370

38. Moon JJ, Chu HH, Pepper M, McSorley SJ, Jameson SC, Kedl RM, et al. Naive CD4(+) T Cell Frequency Varies for Different Epitopes and Predicts 
Repertoire Diversity and Response Magnitude. Immunity (2007) 27:203-13. doi: 10.1016/j.immuni.2007.07.007

39. Murphy DB, Rath S, Pizzo E, Rudensky AY, George A, Larson JK, et al. Monoclonal Antibody Detection of a Major Self Peptide. MHC Class II Complex. J Immunol (1992) 148:3483-91.

40. Rudensky A, Rath S, Preston-Hurlburt P, Murphy DB, Janeway CA Jr. On the Complexity of Self. Nature (1991) 353:660-2. doi: 10.1038/353660a0

41. Dadaglio G, Nelson CA, Deck MB, Petzold SJ, Unanue ER. Characterization and Quantitation of Peptide-MHC Complexes Produced From Hen Egg Lysozyme Using a Monoclonal Antibody. Immunity (1997) 6:727-38. doi: 10.1016/S1074-7613(00)80448-3

42. Zhou M, Sacirbegovic F, Zhao K, Rosenberger S, Shlomchik WD. T Cell Exhaustion and a Failure in Antigen Presentation Drive Resistance to the Graft-Versus-Leukemia Effect. Nat Commun (2020) 11:4227. doi: 10.1038/ s41467-020-17991-y

43. Warren EH, Zhang XC, Li SY, Fan WH, Storer BE, Chien JW, et al. Effect of MHC and Non-MHC Donor/Recipient Genetic Disparity on the Outcome of Allogeneic HCT. Blood (2012) 120:2796-806. doi: 10.1182/blood-2012-04347286

44. Koyama M, Cheong M, Markey KA, Gartlan KH, Kuns RD, Locke KR, et al. Donor Colonic CD103+ Dendritic Cells Determine the Severity of Acute Graft-Versus-Host Disease. J Exp Med (2015) 212:1303-21. doi: 10.1084/ jem.20150329

45. Wang W, Meadows LR, den Haan JM, Sherman NE, Chen Y, Blokland E, et al. Human H-Y: A Male-Specific Histocompatibility Antigen Derived From the SMCY Protein. Science (1995) 269:1588-90. doi: 10.1126/science.7667640

46. Vogt MH, de Paus RA, Voogt PJ, Willemze R, Falkenburg JH. DFFRY Codes for a New Human Male-Specific Minor Transplantation Antigen Involved in Bone Marrow Graft Rejection. Blood (2000) 95:1100-5. doi: 10.1182/ blood.V95.3.1100.003k42_1100_1105

47. Vogt MH, van den Muijsenberg JW, Goulmy E, Spierings E, Kluck P, Kester MG, et al. The DBY Gene Codes for an HLA-DQ5-Restricted Human MaleSpecific Minor Histocompatibility Antigen Involved in Graft-Versus-Host Disease. Blood (2002) 99:3027-32. doi: 10.1182/blood.V99.8.3027

48. Vogt MH, Goulmy E, Kloosterboer FM, Blokland E, de Paus RA, Willemze R, et al. UTY Gene Codes for an HLA-B60-Restricted Human Male-Specific Minor Histocompatibility Antigen Involved in Stem Cell Graft Rejection: Characterization of the Critical Polymorphic Amino Acid Residues for T-Cell Recognition. Blood (2000) 96:3126-32. doi: 10.1182/blood.V96.9.3126

49. Koyama M, Mukhopadhyay P, Schuster IS, Henden AS, Hulsdunker J, Varelias A, et al. MHC Class II Antigen Presentation by the Intestinal Epithelium Initiates Graft-Versus-Host Disease and Is Influenced by the Microbiota. Immunity (2019) 51:885-98.e7. doi: 10.1016/j.immuni.2019.08.011

50. Gartlan KH, Koyama M, Lineburg KE, Chang K, Ensbey KS, Kuns RD, et al. Donor T-Cell-Derived GM-CSF Drives Alloantigen Presentation by Dendritic Cells in the Gastrointestinal Tract. Blood Adv (2019) 3:2859-65. doi: 10.1182/ bloodadvances.2019000053

51. Bevan MJ. High Determinant Density May Explain the Phenomenon of Alloreactivity. Immunol Today (1984) 5:128-30. doi: 10.1016/0167-5699(84) 90233-0

52. Ford WL, Simmonds SJ, Atkins RC. Early Cellular Events in a Systemic GraftVs-Host Reaction .2. Autoradiographic Estimates of Frequency of Donor Lymphocytes Which Respond to Each Ag-B-Determined Antigenic Complex. J Exp Med (1975) 141:681-96. doi: 10.1084/jem.141.3.681

53. Matzinger P, Bevan MJ. Hypothesis - Why Do So Many Lymphocytes Respond to Major Histocompatibility Antigens. Cell Immunol (1977) 29:15. doi: 10.1016/0008-8749(77)90269-6

54. Rossjohn J, McCluskey J. How a Home-Grown T Cell Receptor Interacts With a Foreign Landscape. Cell (2007) 129:19-20. doi: 10.1016/j.cell.2007.03.018

55. Colf LA, Bankovich AJ, Hanick NA, Bowerman NA, Jones LL, Kranz DM, et al. How a Single T Cell Receptor Recognizes Both Self and Foreign MHC. Cell (2007) 129:135-46. doi: 10.1016/j.cell.2007.01.048

56. Tallquist MD, Yun TJ, Pease LR. A Single T Cell Receptor Recognizes Structurally Distinct MHC/peptide Complexes With High Specificity. J Exp Med (1996) 184:1017-26. doi: 10.1084/jem.184.3.1017

57. Santori FR, Kieper WC, Brown SM, Lu Y, Neubert TA, Johnson KL, et al. Rare, Structurally Homologous Self-Peptides Promote Thymocyte Positive Selection. Immunity (2002) 17:131-42. doi: 10.1016/S1074-7613(02)00361-8
58. Tallquist MD, Weaver AJ, Pease LR. Degenerate Recognition of Alloantigenic Peptides on a Positive-Selecting Class I Molecule. J Immunol (1998) 160:802-9.

59. Burrows SR, Silins SL, Moss DJ, Khanna R, Misko IS, Argaet VP. T Cell Receptor Repertoire for a Viral Epitope in Humans Is Diversified by Tolerance to a Background Major Histocompatibility Complex Antigen. J Exp Med (1995) 182:1703-15. doi: 10.1084/jem.182.6.1703

60. Schulze DH, Pease LR, Geier SS, Reyes AA, Sarmiento LA, Wallace RB, et al. Comparison of the Cloned H-2Kbm1 Variant Gene With the H-2Kb Gene Shows a Cluster of Seven Nucleotide Differences. Proc Natl Acad Sci USA (1983) 80:2007-11. doi: 10.1073/pnas.80.7.2007

61. McIntyre KR, Seidman JG. Nucleotide Sequence of Mutant I-A Beta Bm12 Gene is Evidence for Genetic Exchange Between Mouse Immune Response Genes. Nature (1984) 308:551-3. doi: 10.1038/308551a0

62. McKenzie IF, Morgan GM, Sandrin MS, Michaelides MM, Melvold RW, Kohn HI. B6.C-H-2bm12. A New H-2 Mutation in the I Region in the Mouse. J Exp Med (1979) 150:1323-38. doi: 10.1084/jem.150.6.1323

63. Kranz DM, Sherman DH, Sitkovsky MV, Pasternack MS, Eisen HN. Immunoprecipitation of Cell Surface Structures of Cloned Cytotoxic T Lymphocytes by Clone-Specific Antisera. Proc Natl Acad Sci USA (1984) 81:573-7. doi: 10.1073/pnas.81.2.573

64. Sha WC, Nelson CA, Newberry RD, Kranz DM, Russell JH, Loh DY. Selective Expression of an Antigen Receptor on CD8-Bearing T Lymphocytes in Transgenic Mice. Nature (1988) 335:271-4. doi: 10.1038/335271a0

65. Chen J, Eisen HN, Kranz DM. A Model T-Cell Receptor System for Studying Memory T-Cell Development. Microbes Infect (2003) 5:233-40. doi: 10.1016/ S1286-4579(03)00016-9

66. Brennan TV, Hoang V, Garrod KR, Liu FC, Hayden T, Kim J, et al. A New TCell Receptor Transgenic Model of the CD4+ Direct Pathway: Level of Priming Determines Acute Versus Chronic Rejection. Transplantation (2008) 85:247-55. doi: 10.1097/TP.0b013e31815e883e

67. Sprent J, Schaefer M, Lo D, Korngold R. Properties of Purified T Cell Subsets: II. In Vivo Responses to Class I vs. Class II H-2 Differences. J Exp Med (1986) 163:998. doi: 10.1084/jem.163.4.998

68. Teshima T, Ordemann R, Reddy P, Gagin S, Liu C, Cooke KR, et al. Acute Graft-Versus-Host Disease Does Not Require Alloantigen Expression on Host Epithelium. Nat Med (2002) 8:575-81. doi: 10.1038/nm0602-575

69. Pease LR, Schulze DH, Pfaffenbach GM, Nathenson SG. Spontaneous H-2 Mutants Provide Evidence That a Copy Mechanism Analogous to Gene Conversion Generates Polymorphism in the Major Histocompatibility Complex. Proc Natl Acad Sci USA (1983) 80:242-6. doi: 10.1073/pnas.80.1.242

70. Geliebter J, Nathenson SG. Microrecombinations Generate Sequence Diversity in the Murine Major Histocompatibility Complex: Analysis of the Kbm3, Kbm4, Kbm10, and Kbm11 Mutants. Mol Cell Biol (1988) 8:4342-52. doi: 10.1128/MCB.8.10.4342

71. Shultz LD, Ishikawa F, Greiner DL. Humanized Mice in Translational Biomedical Research. Nat Rev Immunol (2007) 7:118-30. doi: 10.1038/nri2017

72. Kawasaki Y, Sato K, Hayakawa H, Takayama N, Nakano H, Ito R, et al. Comprehensive Analysis of the Activation and Proliferation Kinetics and Effector Functions of Human Lymphocytes, and Antigen Presentation Capacity of Antigen-Presenting Cells in Xenogeneic Graft-Versus-Host Disease. Biol Blood Marrow Transplant (2018) 24:1563-74. doi: 10.1016/ j.bbmt.2018.04.016

73. Covassin L, Laning J, Abdi R, Langevin DL, Phillips NE, Shultz LD, et al. Human Peripheral Blood CD4 T Cell-Engrafted Non-Obese Diabetic-Scid IL2rgamma(null) H2-Ab1 (Tm1gru) Tg (Human Leucocyte Antigen DRelated 4) Mice: A Mouse Model of Human Allogeneic Graft-Versus-Host Disease. Clin Exp Immunol (2011) 166:269-80. doi: 10.1111/j.13652249.2011.04462.x

74. Brehm MA, Cuthbert A, Yang C, Miller DM, Dilorio P, Laning J, et al. Parameters for Establishing Humanized Mouse Models to Study Human Immunity: Analysis of Human Hematopoietic Stem Cell Engraftment in Three Immunodeficient Strains of Mice Bearing the IL2rgamma(null) Mutation. Clin Immunol (2010) 135:84-98. doi: 10.1016/j.clim.2009.12.008

75. Brehm MA, Kenney LL, Wiles MV, Low BE, Tisch RM, Burzenski L, et al. Lack of Acute Xenogeneic Graft- Versus-Host Disease, But Retention of TCell Function Following Engraftment of Human Peripheral Blood Mononuclear Cells in NSG Mice Deficient in MHC Class I and II Expression. FASEB J (2019) 33:3137-51. doi: 10.1096/fj.201800636R 
76. King MA, Covassin L, Brehm MA, Racki W, Pearson T, Leif J, et al. Human Peripheral Blood Leucocyte non-Obese Diabetic-Severe Combined Immunodeficiency Interleukin-2 Receptor Gamma Chain Gene Mouse Model of Xenogeneic Graft-Versus-Host-Like Disease and the Role of Host Major Histocompatibility Complex. Clin Exp Immunol (2009) 157:104-18. doi: 10.1111/j.1365-2249.2009.03933.x

77. Lucas PJ, Shearer GM, Neudorf S, Gress RE. The Human Antimurine Xenogeneic Cytotoxic Response. I. Dependence on Responder AntigenPresenting Cells. J Immunol (1990) 144:4548-54.

78. Lucas PJ, Bare CV, Gress RE. The Human Anti-Murine Xenogeneic Cytotoxic Response. II. Activated Murine Antigen-Presenting Cells Directly Stimulate Human T Helper Cells. J Immunol (1995) 154:3761-70.

79. Shultz LD, Saito Y, Najima Y, Tanaka S, Ochi T, Tomizawa M, et al. Generation of Functional Human T-Cell Subsets With HLA-Restricted Immune Responses in HLA Class I Expressing NOD/SCID/IL2r Gamma(Null) Humanized Mice. Proc Natl Acad Sci USA (2010) 107:13022-7. doi: 10.1073/pnas.1000475107

80. Billerbeck E, Horwitz JA, Labitt RN, Donovan BM, Vega K, Budell WC, et al. Characterization of Human Antiviral Adaptive Immune Responses During Hepatotropic Virus Infection in HLA-Transgenic Human Immune System Mice. J Immunol (2013) 191:1753-64. doi: 10.4049/jimmunol.1201518

81. Schroder K, Hertzog PJ, Ravasi T, Hume DA. Interferon-Gamma: An Overview of Signals, Mechanisms and Functions. J Leukoc Biol (2004) 75:163-89. doi: 10.1189/jlb.0603252

82. Ting JP, Trowsdale J. Genetic Control of MHC Class II Expression. Cell (2002) 109 Suppl:S21-33. doi: 10.1016/S0092-8674(02)00696-7

83. Ehx G, Somja J, Warnatz HJ, Ritacco C, Hannon M, Delens L, et al. Xenogeneic Graft-Versus-Host Disease in Humanized NSG and NSG-HLA-A2/HHD Mice. Front Immunol (2018) 9:1943. doi: 10.3389/fimmu.2018.01943

84. Stevanovic S, Nijmeijer BA, van Schie ML, Salvatori DC, Maas S, Griffioen M, et al. Donor T Cells Administered Over HLA Class II Barriers Mediate Antitumor Immunity Without Broad Off-Target Toxicity in a NOD/scid Mouse Model of Acute Leukemia. Biol Blood Marrow Transplant (2013) 19:867-75. doi: 10.1016/j.bbmt.2013.03.003

85. Alhaj Hussen K, Michonneau D, Biajoux V, Keita S, Dubouchet L, Nelson E, et al. CD4(+)CD8(+) T-Lymphocytes in Xenogeneic and Human GraftVersus-Host Disease. Front Immunol (2020) 11:579776. doi: 10.3389/ fimmu.2020.579776

86. Ishikawa F, Yasukawa M, Lyons B, Yoshida S, Miyamoto T, Yoshimoto G, et al. Development of Functional Human Blood and Immune Systems in
NOD/SCID/IL2 Receptor \{Gamma\} Chain(Null) Mice. Blood (2005) 106:1565-73. doi: 10.1182/blood-2005-02-0516

87. Shultz LD, Lyons BL, Burzenski LM, Gott B, Chen X, Chaleff S, et al. Human Lymphoid and Myeloid Cell Development in NOD/LtSz-Scid IL2R Gamma Null Mice Engrafted With Mobilized Human Hemopoietic Stem Cells. J Immunol (2005) 174:6477-89. doi: 10.4049/jimmunol.174.10.6477

88. Wunderlich M, Chou FS, Sexton C, Presicce P, Chougnet CA, Aliberti J, et al. Improved Multilineage Human Hematopoietic Reconstitution and Function in NSGS Mice. PloS One (2018) 13:e0209034. doi: 10.1371/journal. pone.0209034

89. Wunderlich M, Chou FS, Link KA, Mizukawa B, Perry RL, Carroll M, et al. AML Xenograft Efficiency Is Significantly Improved in NOD/SCIDIL2RG Mice Constitutively Expressing Human SCF, GM-CSF and IL-3. Leukemia (2010) 24:1785-8. doi: 10.1038/leu.2010.158

90. Rongvaux A, Willinger T, Martinek J, Strowig T, Gearty SV, Teichmann LL, et al. Development and Function of Human Innate Immune Cells in a Humanized Mouse Model. Nat Biotechnol (2014) 32:364-72. doi: 10.1038/ nbt. 2858

Author Disclaimer: The content is solely the responsibility of the authors and does not necessarily represent the official views of the NIH.

Conflict of Interest: GRH has consulted for Generon Corporation, NapaJen Pharma, Neoleukin Therapeutics. iTeos Therapeutics and has received research funding from Roche, Compass Therapeutics, Syndax Pharmaceuticals, Applied Molecular Transport and iTeos Therapeutics.

Publisher's Note: All claims expressed in this article are solely those of the authors and do not necessarily represent those of their affiliated organizations, or those of the publisher, the editors and the reviewers. Any product that may be evaluated in this article, or claim that may be made by its manufacturer, is not guaranteed or endorsed by the publisher.

Copyright (C) 2021 Koyama and Hill. This is an open-access article distributed under the terms of the Creative Commons Attribution License (CC BY). The use, distribution or reproduction in other forums is permitted, provided the original author(s) and the copyright owner(s) are credited and that the original publication in this journal is cited, in accordance with accepted academic practice. No use, distribution or reproduction is permitted which does not comply with these terms. 